\title{
The rocky road of interregionalism: EU sanctions against human rights-violating Myanmar and repercussions on ASEAN-EU relations
}

\author{
Kerstin Schembera \\ University of Konstanz
}

\begin{abstract}
From 1991 until 2012, the European Union (EU) applied sanctions on Myanmar with the purpose of promoting democracy and human rights. In addition, the EU called on the Association of Southeast Asian Nations (ASEAN) to exert pressure on Myanmar. This paper analyses, in the context of Myanmar's 1997 accession to ASEAN, how the EU's sanctions approach towards Myanmar was perceived within ASEAN and related repercussions of this approach on ASEAN-EU interregional relations. With the accession of Myanmar as the base story, it is argued that a regional organizations membership concept implies specific dealings with normative ideas such as democracy and human rights as well as strategies of punishment such as sanctions. The differing membership concepts of ASEAN and the EU explain ASEAN's critical perception of the EU's sanctions on Myanmar. Further, the conceptual difference in membership also explains that the EU's pressure on ASEAN has severely impaired the interregional relations.
\end{abstract}

\section{Introduction}

Since the 1990s, interactions between regions are an increasing phenomenon for managing and balancing relations in a globalizing world. Nowadays, 'almost all regions and subregions engage in some sort of institutionalized interregional activities' (Hänggi et al 2006, 31). Regional organizations (ROs) thereby are the 'major actors structuring relations between regions' (Hänggi et al 2006, 34). However, the road of interregionalism is often quite rocky, involving conflicts between ROs. These can range from disputes concerning trade cooperation to issues more concerned with political cooperation. Often, the public does not take note of such conflicts, as they appear behind the scenes of interregional relations and rather lead to stasis in such formats that anyways are mostly conducted in an 'ad hocist, intermittent and noncommittal' (Hänggi et al 2006, 7) way. The interactions of the Association of Southeast Asian Nations (ASEAN) and the European Union

The author would like to thank the three anonymous reviewers for their constructive and supportive comments on the article. Special thanks to Clara Portela for her excellent feedback and for sharing her sanctions research expertise. Further, thanks to Sara(h) Kraus, Daniela Kroll, Dirk Leuffen, Jürgen Rüland, Stefan Schembera, Sophia Schemel and Anke Wiedemann for helpful literature, suggestions and discussions on the article. 
(EU) over the case of the Republic of the Union of Myanmar, ${ }^{1}$ however, constitute an example of open interregional conflict from which we can gain insights about the ways ROs interact and why they sometimes clash. The context to this example is set by the EU which applied sanctions towards Myanmar from 1991 until 2012 with the purpose of promoting democracy and human rights. It additionally took measures at the interregional level, calling on ASEAN to remind Myanmar of human rights standards or even refuse $\mathrm{RO}$ membership to the country, thereby trying to pressure the country via its regional peers. ASEAN also had concerns to some extent; however, it envisioned Myanmar as part of the Southeast Asian family and consequently chose another approach towards the country. Under the idea of 'constructive engagement', ASEAN followed a practice of encouraging moderate political change and the country's move towards democracy by involving the leaders of the State Law and Order Restoration Council (SLORC) in regional processes. Hence, ASEAN aimed at keeping access to the junta (see for example Jones 2012). As part of this strategy, it accepted the country as an observer in 1996 and full member in 1997. Clearly, the EU's approach of isolating Myanmar through sanctions became an irritant in ASEAN-EU relations, substantiated by several interregional meetings being postponed or cancelled (see Dosch 2001; Portela 2015; Boisseau du Rocher 2012; Rüland 2000).

This paper investigates how the EU's sanctions approach towards Myanmar was perceived within ASEAN in the context of Myanmar's accession to ASEAN. Linked to that, the consequences of this approach on the ASEAN-EU interregional relationship are evaluated. The article argues that taking into account an RO's membership concept is essential in interregional relations. In fact, an RO's membership concept specifies how to deal with norms of appropriate behaviour, such as democracy and human rights, as well as with strategies of punishment, such as sanctions, towards (prospective) members. If a membership question, which in a narrow sense only concerns the RO that supplies the membership, is transported towards the interregional level, differing membership concepts can cause interregional conflict. The empirical analysis will show that the membership concepts of ASEAN and the EU at the time of Myanmar's accession process differed, especially on the question of membership timing or membership sequencing - that is, which step comes first in an accession process - as well as the question of how to deal with domestic democratic reform. In the case of interregional conflict over Myanmar, the differing membership concepts thus explain ASEAN's critical perception of the EU's approach. Importantly, it is argued that the EU's pressure on ASEAN concerning the Myanmar issue has severely impaired interregional relations. In the remainder of this article, I present theoretical considerations about why membership rules matter in interregional relations. I then introduce the case study of ASEAN-EU relations over Myanmar, giving vital information about the EU's sanctions towards Myanmar as well as its pressure towards ASEAN. Finally, the case study includes an analysis of the Southeast Asian perception about the EU's sanctioning approach towards Myanmar, reflected in the discourse between ASEAN officials and other members of the Southeast Asian elites. The analysis draws on expert interviews, primary and secondary data addressing the role of ASEAN and the EU in the Myanmar conflict.

${ }^{1}$ Hereafter called 'Myanmar'. 'Burma' or 'Burmese' is used in this article only when citing sources that recurred to these terms. The choice of 'Myanmar' was made without any prejudice about the correctness of any of these names. 


\section{Interregional conflicts and 'Myanmar in ASEAN-EU relations' studies}

Early forms of interregionalism developed in the 1970s with ASEAN and the EU as pioneers. With the real take-off for interregional relations in the 1990 s only, interregionalism is 'a novelty in international relations' (Hänggi et al 2006, 6), and research on this phenomenon is still in early stages. So far, analyses have focused on explaining interregionalism and its emergence, forms and performance as well as how it affects regionalism and regional identity-building. From a broader international relations perspective, its value added to the international system was investigated (for an overview of interregionalism studies see Rüland 2014). Empirical insights were mostly gained from studies focusing on interregional formats that involved actors from North America, Europe and East Asia, with the majority looking at the Asia-Europe meeting (ASEM; Gaens 2008; Robles Jr 2008; Yeo 2003; Reiterer 2002) or ASEAN-EU relations more specifically (Allison 2015; Robles Jr 2004; Dosch 2001; Novotny and Portela 2012). Despite an ebbing away of interregionalism studies and a shifting focus towards other issues of global governance in recent years, there are still questions that research should address. For instance, the ideational dimension of interregionalism is promising, but still not sufficiently studied (see Rüland 2014). In addition, one aspect has so far received only limited attention: the question of why conflicts arise in interregional activities. While there are many studies that empirically discuss, for example, normative differences between Europe and Asia (see for example Petersson 2006; Gaens 2008; Palmujoki 1997), theoretical or conceptual considerations about interregional conflict are rather missing. In a broad sense, Rüland (2015) approaches the issue by analysing normative and conceptual misunderstandings between ASEAN and the EU, although his analysis is more focused on capacity-building through interregionalism. Other studies of ASEAN-EU interregionalism specifically disclosed how ASEAN-EU interactions over human rights, in general and not limited to the Myanmar case, have contributed to ASEAN's identity formation (Manea 2009, 2008). Manea's studies revealed a conceptual disagreement about human rights between the two ROs, though considering more the consequences than the causes of this. My analysis of the Myanmar accession case in interregional relations shows that the disagreement is even broader and encompasses membership concepts and their relation to sanctions and human rights. Some studies analysed the Myanmar issue in an interregional perspective, but not in the specific 1997 accession context (Portela 2015). Other analyses examined the Myanmar issue from the perspective of one $\mathrm{RO}$ mostly, but not explicitly in an interregional perspective. In EU research, we find accounts of the sanctions policy towards Myanmar as part of EU foreign policy (Portela 2011) and the development of the EU's position over time (Marchi 2014). ASEAN scholarship extensively investigated ASEAN's Myanmar policy (Roberts 2010; Davies 2012; Katanyuu 2006), producing valuable accounts that albeit did not fully incorporate the EU dimension beyond generalities. My paper contributes to the literature on interregionalism by providing a detailed analysis of the Myanmar case, allowing insights into why ROs sometimes clash and which role $\mathrm{RO}$ membership concepts play in such interregional clashes. In addition, this paper follows the call by scholars and practitioners to examine mutual perceptions between Europe and Asia, especially concerning human rights affairs (see Holland and Chaban 2015; Villacorta 2009), as perceptions are 
an important 'explanatory variable in the study of relations between the EU and Asia' (Bersick 2015, 329).

\section{Theoretical considerations: interregionalism and RO membership concepts}

Interregional interactions are part of the international relations of a region. Theorizing international relations, constructivism offers an explanation for conflicts in interregional relations and the role membership concepts play in such formats. From a constructivist perspective, conflict in interregionalism can be seen as a point where regional cooperation cultures are not compatible (see Rüland et al $2008,10)$. These regional cooperation cultures are based on the 'community ethos' of an $\mathrm{RO}$, which is defined by the 'constitutive values and norms that define the collective identity of the community' (Schimmelfennig 2003, 7). This includes that a community defines "who "we" are, what "we" stand for and how "we" differ from others' (Schimmelfennig 2003, 7). In a constructivist perspective, ideational factors such as norms-that is, 'shared expectations about appropriate behavior held by a collectivity of actors' (Checkel 1999, 83) — and identity are emphasized for analysing and explaining actors' logic of action. In this reading, norms not only regulate but also shape behaviour, and shared beliefs construct interests of purposive actors. Interregionalism also is a practice of interaction where distinct regional identities and norms meet, as it constitutes an act of regions advancing their own regional profiles (see Gilson 2005). This externalization of a region's own cooperation culture in interregional settings bears potential for conflict, especially over the validity or interpretation of norms. Regional cooperation culture and an RO's membership concept are intertwined, defining and specifying how to deal with political norms such as democracy and human rights as well as with strategies of punishment, such as sanctions, towards (prospective) members. If a membership question, which in a narrow sense only concerns the RO that supplies the membership, is transported towards the interregional level, differing membership concepts of ROs can cause interregional conflict. Accordingly, relations can be strained by differences in cooperation cultures. In its core, the ASEANEU interregional conflict over Myanmar is a normatively embossed conflict about political norms such as democracy and human rights and their relation with an RO's membership concept. Consequently, this paper applies a conceptual lens of $\mathrm{RO}$ membership to analyse the case of interregional conflict over the accession of Myanmar along six key dimensions. The dimensions were identified through existing literature on $\mathrm{RO}$ membership.

\section{Nature of membership}

Regional organizations differ in the nature of membership and related rules ranging "from "Convoy" rules that allow all regional states to participate unconditionally to "club" rules that enforce strict criteria for admission and continued participation' (Kelley 2013, 78). Membership rules reflect the member states' 'willingness to make binding commitments to a common cause' (Kelley 2013, 78), which depends on the RO's composition of countries and thus degree of heterogeneity. These rules in turn 'shape the tools organizations can use to reduce state heterogeneity' (Kelley 2013, 79). The more heterogeneous an RO, the lower the 
barriers it is expected to set for membership rules and the weaker the instruments it has at its disposal or the less willing it might be to change heterogeneity. In the $\mathrm{EU}$, accession is tied to the fulfilment of the Copenhagen criteria laid down in the Treaty on European Union (TEU) Article 49 and Article 6(1). ASEAN, showing a much more heterogeneous composition of nation states, prescribes no such conditions and only makes requirements of geographical and technical character. This difference in membership conditions also becomes apparent in the duration of accession processes. While they might stretch over years or decades of monitoring reforms in the EU, they proceed quicker in ASEAN, being solely approved by the heads of state or government, but not by member states' parliaments.

\section{State sovereignty}

Another dimension concerns the conception of national sovereignty in regional integration, which is the right and power of regulating domestic affairs within RO context. The EU and ASEAN significantly differ in this respect: While the EU's foundation rested on the idea of partial delegation of national sovereignty to the supranational level-that means pooling of sovereignty in order to avoid conflict-ASEAN embarked on the opposite idea-absolute national sovereignty within an intergovernmental organization to sidestep skirmishes. ASEAN's sovereignty concept, expressed in the principle of non-interference, prescribes how to deal with domestic affairs and possible 'misbehaviour' of other (member) states. Crucially, in its original form this also demanded rhetorical refrainment from another country's domestic matters.

\section{Behaviour}

Behaviour is another conceptual dimension which is linked to different visions about the socialization of actors-that is, the 'process of inducting actors into the norms and rules of a given community' (Checkel 2005, 804). There are two mechanisms affecting comportment of decision-makers: socialization via incentives or via discursive engagement. These socialization efforts differ along a time component, distinguishing pre- and post-accession. The EU's conditionality strategy follows the idea of reinforcement by rewards (Schimmelfennig et al 2003, 496-497), where incentives aim at creating structures for rational cost-benefit calculating actors to adjust their behaviour before accession. ASEAN's strategy is built on the idea of post-accession socialization, engaging discursively the target to be socialized (see Davies 2014). This interactive approach allows the inclusion of 'outlier states by interacting with them within the organization rather than erecting barriers' (Kelley 2013, 79).

\section{Compliance}

While most, if not all, ROs have compliance with the organization's rules as a key goal, the compliance dimension in RO concepts varies significantly with regard to the role of time. In a predominantly static perspective, immediate ad hoc compliance is required. In a more dynamic perspective, an RO may tolerate an initial phase of non-compliance with its rules for the sake of encouraging incremental 
steps over time through interaction and thus membership and moving towards (full) compliance in the long term (for different perceptions of compliance especially in Western and Southeast Asian contexts see Schembera et al 2015).

\section{Measures in case of non-compliance}

The choice for membership conditions, behaviour and compliance demands determines an RO's enforcement measures in case of non-compliance-that is, moments when $\mathrm{RO}$ rules are breached. Sanctions are one example, but measures in case of non-compliance can also take the form of membership suspension or expulsion. The recourse to such measures depends on how an RO perceives its political mandate (Hellquist 2014, 8). Since the EU understands itself as a liberal-democratic community, its political mandate justifies sanctions in defence of such norms. In contrast, ASEAN avoided commitment or provision towards any kind of political regime from the beginning, with no liberal-democratic norm apparatus that would translate into membership criteria and sanctions. ASEAN only introduced democracy and human rights as principles, but not membership criteria, in its 2008 ASEAN Charter.

\section{Obligations}

Membership in ROs also encompasses obligations, defining what members must accept from or provide the $\mathrm{RO}$ with. EU membership requires the acceptance of the acquis communautaire, the body of common rights and obligations. This entails the commitment for transposition into national legislation and implementation with accession. In ASEAN, countries are required to formally accept all RO treaties. Compared to the EU's acquis communautaire procedure this, however, does not comprise immediate implementation requirements. Table 1 summarizes these six key dimensions for the EU and ASEAN.

The multidimensional character of an RO's membership concept shows that ROs can differ in how to socialize members into human rights and the recourse to sanctions. At the time of Myanmar's potential accession, ASEAN and the EU relied on membership concepts that had competing visions concerning democracy and human rights as well as the application of sanctions. The main issue in the diverging membership concepts was about the timing or sequencing of membership and domestic reform. Therefore, I hypothesize that the EU's sanction approach harmed the ASEAN-EU relationship, as the sanctioning approach towards Myanmar and ASEAN fitted with the EU membership concept, but was incompatible with ASEAN's membership concept and related norms. In ASEAN's discourse, the EU's approach should therefore be rejected on the basis of arguments that refer to ASEAN's concept of membership.

\section{Data}

This paper presents an analysis of ASEAN's perception of the EU's Myanmar approach and the related interregional conflict. The investigation uses data triangulation, thereby assuring validity of the study. Three types of data sources were included: firstly, expert interviews; secondly, documentary data referring to ASEAN and EU membership concepts as well as the case of human rights in Myan- 
Table 1. Membership Concepts in the European Union (EU) and the Association of Southeast Asian Nations (ASEAN)

\begin{tabular}{|c|c|c|}
\hline $\begin{array}{l}\text { Dimensions of } \\
\text { membership }\end{array}$ & EU & ASEAN \\
\hline \multirow[t]{2}{*}{$\begin{array}{l}\text { Nature of member- } \\
\text { ship }\end{array}$} & $\begin{array}{l}\text { Conditional, extensive admission } \\
\text { criteria (TEU Article } 49 \text { and Article } \\
6(1) \text { ) }\end{array}$ & $\begin{array}{l}\text { Unconditional, admission } \\
\text { criteria only of geographic } \\
\text { and technical character (1967 } \\
\text { Bangkok Declaration and } \\
\text { ASEAN Charter, Article 6) }\end{array}$ \\
\hline & Norm body for membership & $\begin{array}{l}\text { No norm body for member- } \\
\text { ship }\end{array}$ \\
\hline \multirow[t]{2}{*}{ State sovereignty } & $\begin{array}{l}\text { Partial delegation of sovereignty } \\
\text { to supranational level }\end{array}$ & Full national sovereignty \\
\hline & $\begin{array}{l}\text { Extension of supranational legisla- } \\
\text { tion into domestic affairs }\end{array}$ & $\begin{array}{l}\text { Non-interference in domestic } \\
\text { affairs, also rhetorically } \\
\text { (ASEAN Charter, Article 2) }\end{array}$ \\
\hline Behaviour & $\begin{array}{l}\text { Pre-accession socialization via } \\
\text { incentives (including rewards) }\end{array}$ & $\begin{array}{l}\text { Post-accession socialization } \\
\text { via discursive engagement, } \\
\text { no rewards or coercion }\end{array}$ \\
\hline Compliance & $\begin{array}{l}\text { Static perspective with immediate } \\
\text { compliance }\end{array}$ & $\begin{array}{l}\text { Dynamic perspective with } \\
\text { incremental compliance }\end{array}$ \\
\hline $\begin{array}{l}\text { Measures in case of } \\
\text { noncompliance }\end{array}$ & $\begin{array}{l}\text { Suspension of membership rights } \\
\text { in case of serious and persistent } \\
\text { breach of common values (Treaty } \\
\text { of Lisbon, Article 7) }\end{array}$ & $\begin{array}{l}\text { No suspension or expulsion } \\
\text { measures }\end{array}$ \\
\hline Obligations & $\begin{array}{l}\text { Acceptance of community acquis, } \\
\text { transposition into national legis- } \\
\text { lation and implementation with } \\
\text { accession }\end{array}$ & $\begin{array}{l}\text { Formal acceptance of } \\
\text { all ASEAN treaties, no im- } \\
\text { mediate implementation re- } \\
\text { quirements (ASEAN Charter, } \\
\text { Articles } 5 \text { and 6) }\end{array}$ \\
\hline
\end{tabular}

Source: Own compilation.

mar; and, thirdly, secondary data. From March to May 2014, I conducted around 25 formal interviews in Indonesia, Malaysia, Myanmar, Philippines, Singapore and Thailand with central actors from ASEAN, national foreign ministries, think tanks and media as well as non-governmental organizations (NGOs) and civil society organizations (CSOs). The interviews are a particularly valuable source of information on how the EU's sanctioning approach was perceived as such and in relation to human rights in Southeast Asia. ${ }^{2}$ In addition to interview data, documentary data are included. The documentary analysis broadens the exploration of perceptions about membership in Southeast Asia by integrating elite perceptions about Myanmar's accession and the concept of membership in ASEAN. The statements were sourced from a selection of articles that were published between 1992 and 2003 in five Southeast Asian newspapers, and were chosen according to the

${ }^{2}$ As the article focuses on the perception of the EU's approach in ASEAN, interviews were conducted with elite representatives in ASEAN. Further research could complement analyses with expert interviews within EU circles. 
membership concept dimensions identified in this study. ${ }^{3}$ Furthermore, official reports and statements from ASEAN and the EU, statements from (trans)regional NGOs and secondary literature are analysed.

\section{Introduction of case study: interregional conflict over Myanmar}

Since the 1988 uprisings in Myanmar that were ended by a bloody military coup, the EU has closely scrutinized the country's developments. Following the junta's non-recognition of the 1990 election results, the EU in 1991 started to impose sanctions (see Bünte 2007; Portela and Vennesson 2013; Marchi 2014) with the aim of publicly condemning the military regime and demonstrating disapproval of human rights abuses. Importantly, the EU was also under high pressure from NGOs to sanction Myanmar. Such restrictive measures are one tool of foreign policy that the EU uses to pursue the objectives of its Common Foreign and Security Policy. According to Article 21 of the TEU, the Union's international action shall be directed 'by the principles which have inspired its own creation, development and enlargement ...: democracy [and] the universality and indivisibility of human rights and fundamental freedoms .....'. ${ }^{4}$ Table 2 summarizes the EU measures directed to Myanmar (for details see Bünte 2007; ALTSEAN-Burma 2003, Pedersen 2008) and relates them to measures directed at the broader regional level-that is, 'quasi-sanctions' on ASEAN-from 1991 onwards

Myanmar's potential membership was discussed in ASEAN since 1993 with considerations about observer status for the country, a step which was then, however, deferred by ASEAN due to human rights concerns (see Radtke 2014; Acharya 2009). The EU also debated the Myanmarese situation since the early stage of the country's potential ASEAN accession. In 1994

the [EU] Ministers noted that there had been some positive developments in Myanmar. They expressed the hope that ASEAN's policy of constructive engagement and the EU's willingness to engage in a critical dialogue will eventually contribute to achieving more sustainable improvements in all fields. ${ }^{5}$

In 1996, the year of ASEAN observer status for Myanmar and its official membership request, the EU intensified sanctions and expressed concern about 'the absence of progress towards democratization and ... the continuing violation of human rights', ${ }^{6}$ demanding respect for fundamental rights, the release of political prisoners, respectful dialogue between all political parties and national reconciliation. In the accession year 1997, the eligibility for Myanmarese products under the

3 The newspapers are Bangkok Post (Thailand), Jakarta Post (Indonesia), Business Times (Philippines), The Straits Times (Singapore) and New Straits Times (Malaysia). All articles are accessible via the database Factiva.

4 Treaty on European Union, <http://eur-lex.europa.eu/legal-content/EN/TXT/PDF/ ?uri=OJ:C:2008:115: FULL\&from=EN>, accessed 20 April 2015. For a comprehensive overview about the legal framework of EU sanctions see Portela (2011).

${ }^{5} 11$ th ASEAN-EU Foreign Ministers Meeting, Karlsruhe, 22-23 September 1994, <http:/ / europa. eu/rapid/press-release_PRES-94-195_en.htm>, accessed 30 May 2015.

${ }^{6}$ Council of the European Union, "96/635/CFSP: Common Position of 28 October 1996 defined by the Council on the basis of Article J.2 of the Treaty on European Union, on Burma/Myanmar", official Journal of the European Union, L287, 28 October 1996, p. 1. <http://eur-lex.europa.eu/legalcontent/EN/TXT/?uri=CELEX: 31996E0635>, accessed 20 April 2015. 
Table 2. Membership Concepts in the European Union (EU) and the Association of Southeast Asian Nations (ASEAN) since 1991

\begin{tabular}{|c|c|}
\hline EU sanctions on Myanmar & EU 'quasi-sanctions' on ASEAN \\
\hline $\begin{array}{l}\text { 1991: Suspension of defence coop- } \\
\text { eration; visa ban for top military } \\
\text { officials; suspension of high-level } \\
\text { bilateral government visits; suspen- } \\
\text { sion of non-humanitarian bi- and } \\
\text { multilateral aid } \\
\text { - 1992: withdrawal of European mili- } \\
\text { tary attachés from Yangon } \\
\text { - 1996: expulsion of Myanmar's mili- } \\
\text { tary and diplomatic personnel from } \\
\text { EU states; embargo on arms, muni- } \\
\text { tions and military equipment; sus- } \\
\text { pension of non-humanitarian aid or } \\
\text { development programmes; visa bans } \\
\text { and suspension of high-level bilateral } \\
\text { governmental visits to Burma } \\
\text { - 1996: Strengthening of arms embargo, } \\
\text { visa ban for specific military members } \\
\text { - 1997: Withdrawal of Generalized Sys- } \\
\text { tem of Preference (GSP) eligibility for } \\
\text { products from Myanmar. } \\
\text { - 1998: Widening of visa ban, extension } \\
\text { to cover Myanmarese authorities in } \\
\text { the tourism sector. } \\
\text { - Since 1999: Extensions and updates of } \\
\text { visa bans and blacklists }\end{array}$ & $\begin{array}{l}\text { - 1997: Cancellation of Joint Coop- } \\
\text { eration Council (JCC) meeting } \\
\text { (Bangkok, November 1997) due to } \\
\text { differences between ASEAN and } \\
\text { EU about Myanmar's participant } \\
\text { status (passive presence vs. full } \\
\text { observer status) } \\
\text { - 1998-2000: Cancellation of sever- } \\
\text { al ministerial meetings and JCC } \\
\text { meetings } \\
\text { - 1999: Second cancellation of JCC } \\
\text { Bangkok meeting due to differenc- } \\
\text { es about meeting formalities con- } \\
\text { cerning Myanmar's participation } \\
\text { - Since 1998: Postponement of devel- } \\
\text { opment programmes } \\
\text { - Since 1998: Delays in Asia-Europe } \\
\text { Meeting (ASEM) process. }{ }^{10}\end{array}$ \\
\hline
\end{tabular}

Source: Own compilation.

Generalised System of Preferences (GSP) was withdrawn. This approach, comprising sanctions, contrasted with ASEAN's approach of 'constructive engagement'. Crucially, ASEAN also had quite strong expectations of Myanmar changing its ways after accession; however, it believed in other concepts for promoting and

${ }^{7}$ General Affairs Council Declaration, 29 July 1991.

${ }^{8} 1996$ th Council meeting, General Affairs, Brussels, 24 March 1997, 6491/97, C/97/68, <http:// europa.eu/rapid/press-release_PRES-97-68_en.htm>, accessed 20 April 2015.

${ }_{9}^{2}$ 2126th Council meeting, General Affairs, Luxembourg, 26 October 1998,<http://europa.eu/ rapid/press-release_PRES-98-351_en.htm?locale=en>, accessed 20 April 2015.

${ }^{10}$ As this study adopts a broad perspective on the consequences of the EU's approach on Southeast Asia and ASEAN specifically, the list of 'quasi-sanctions' also includes the (ASEM), a dialogue forum between Europe and East Asia. The EU initially refused to accept Myanmar's 'automatic' ASEM membership as a result of its ASEAN membership. ASEAN issued boycott threats, and subsequent discussions about enlargement modalities resulted in deadlocks. For a detailed analysis on the Myanmar ASEM issue see Davies (2012), and on the ASEM process see Robles Jr. (2008), Manea (2009), Keva (2008). 
securing these goals. Notably, ASEAN stretched its non-interference norm and, in an approach of quiet diplomacy, interacted with Myanmarese leaders (Jones 2010, 2012; Rüland 2000). Hence, the two ROs in their interregional activities discussed a topic while holding competing ideas about how to socialize the country into human rights standards. "The argument of diversity of vision took broader shape that same year, 1996, when [ASEAN] granted observer status to Myanmar' (Marchi 2014, 63), and accession then seriously challenged the RO's credibility and foreign relations (see Boisseau du Rocher 2012, 166). In addition, it is crucial to note that the EU applied pressure against Myanmar at the regional level, specifically in the context of ASEAN enlargement. Quite importantly, this enlargement had consequences on the interregional level, generating questions about the participant circle of the 1980 'EC-ASEAN Cooperation Agreement', ${ }^{11}$ which originally limited application to 'the territories in which the Treaty establishing the European Economic Community is applied' as well as to the ASEAN members of 1980. In 1998, after evaluation of the situation in Myanmar, the EU decided:

although Burma has become a member of ASEAN, the EU cannot agree to Burmese accession to the EC-ASEAN Agreement. However ... it has decided to accept a Burmese presence, under special conditions to be agreed upon, at the next meeting of the Joint Committee under the EC-ASEAN Agreement. ${ }^{12}$

In the following years the EU, in light of the situation in Myanmar, refused the country's participation in ASEAN-EU meetings and denied visa to the Myanmar foreign minister for meetings in EU countries. In sum, the EU also transferred its originally bilateral occupation with Myanmar towards the interregional ASEANEU level, although these relations were conducted in an explicitly interregional format; for example the ASEAN-EU dialogues or the ASEM process. It is these interregional dialogues that the EU used as a forum to articulate its critique concerning one individual country.

\section{ASEAN's perception of the EU's Myanmar approach via ASEAN}

This section empirically analyses how ASEAN perceived the EU's approach towards ASEAN in the Myanmar issue. In the following, the RO membership concept dimensions are applied to the case of ASEAN and EU strategies towards Myanmar and human rights.

\section{Nature of membership}

At the time of Myanmar's potential accession, ASEAN's legal framework did not include any democracy or human rights criteria, as '[h]aving criteria beyond geography would be against the ASEAN principle of inclusiveness' ${ }^{13}$ - the found-

${ }^{11}$ Cooperation Agreement, 7 March 1980, Kuala Lumpur, Official Journal of the European Communities, No. L 144/2, 10.6.1980 < http://ec.europa.eu/world/agreements/downloadFile. do?fullText=yes\&treatyTransId=815>, accessed 20 April 2015.

12 2126th Council meeting Common Position, General Affairs, Luxembourg, 26 October 1998, C/98/351, 12274/98, <http://europa.eu/rapid/press-release_PRES-98-351_en.htm?locale=en>, accessed 20 April 2015.

${ }^{13}$ Interview with Rodolfo Severino, ASEAN Secretary-General from 1998 to 2003, 14 April 2014. 
ing vision 'One Southeast Asia' of assembling all the region's countries under one roof. Consequently, ASEAN's Myanmar strategy comprised neither concrete public demands towards the junta nor any ideas about democracy or human rights norms as membership prerequisites. Accession documents for Myanmar do not refer to any fundamental political norms (ASEAN 1997a, 1997b, 1997c). In fact, although respect for humanitarian values was not a formal criterion in 1997, informal human rights activities - also with official ASEAN participation-did develop in the region since the early 1990s. Hence, ideas about formal democracy or human rights standards were just evolving and became part of the regional level much later. However, '[i]n the absence of conditionality, an organization can still use the elevated position of joint statements in the name of that organization to forward statements of unalterable belief with the desire to condition behavioural response' (Davies 2012, 11). ${ }^{14}$ ASEAN did so, for example, in 2003 when it demanded the release of the opposition leader in Myanmar (ASEAN 2003). On the contrary, the EU-convinced about the universality of human rights and being an $\mathrm{RO}$ that demands appropriate behaviour from members-applied this conditionality notion in the interregional dialogues, calling on ASEAN to admit Myanmar only after fulfilment of conditions. After a 1997 ASEAN-EU meeting, then foreign minister of Singapore, Shunmugam Jayakumar, remarked: 'The Europeans urged Asean to negotiate a pre-nuptial agreement with Myanmar before admitting her to Asean. One Asean minister's response was that in Asia, we marry first and expect the bride to adapt her behaviour after the marriage' (Chew 1997).

However, at the time of Myanmar's potential accession, this demand did not fit with ASEAN's membership concept, as '[t]he system we started off was not on conditionalities, but accepting that we are all different' ${ }^{\prime}{ }^{15}$ Hence, the pressuring mechanism via ASEAN was received repudiatively in ASEAN.

\section{State sovereignty}

The different conceptions of national sovereignty in the two ROs also impeded a concerted action towards Myanmar. ASEAN, at the official level, referred to the principle of non-interference, conceiving human rights problems as Myanmar's internal affairs, as Rodolfo Severino-then Philippine undersecretary for foreign affairs-stressed:

While Myanmar politics is the internal affair of the people there, we would, of course, wish them well in the promotion of political stability. We are not telling the Myanmarese what to do. It's up to them to sort this out. (Sawatsawang and Manibhandu 1996)

In fact, ASEAN in the background interpreted this non-interference norm in a flexible way, conducting behind-the-scenes conversations with Myanmarese leaders in order to promote democratic ideals. ${ }^{16}$ However, refusing membership on the basis of human rights violations, as the EU envisioned in the discussion, would

\footnotetext{
14 ASEAN from 2001 onwards used public pronouncements to express its displeasure with developments in Myanmar.

${ }^{15}$ Interview with Shunmugam Jayakumar, Singapore Foreign Minister Singapore 1994-2004, 17 April 2014

${ }^{16}$ Critical analyses have shown that indeed the non-interference norm was violated in other cases; see Portela (2011) or Rüland (2000).
} 
have conflicted with the norm of non-interference that is officially part of ASEAN's community ethos, the 'ASEAN Way'.

\section{Behaviour}

The discussion about Myanmar and how to influence the governing elites' behaviour was led in the context of diverging socialization pressures concerning human rights in ROs (see Davies 2014, 25). ASEAN applied 'constructive engagement', by which it hoped to keep the lines of communication with the junta open and 'would actively try to persuade SLORC to change its ways' (Jones 2012, 186). 'ASEAN worked behind the scene, taking every opportunity to encourage Myanmar to commit themselves on the road of democracy and open up the country. ${ }^{17}$

This 'was a way to draw Myanmar slowly into a web of promises and friendly peer pressure' (Davies 2012, 6), with the ultimate aim of socializing it into appropriate behaviour. Pushing the country towards democracy and human rights, though, was not the only concern under 'constructive engagement', but also the refugee problem or the broader economic development were part of ASEAN's considerations. Engagement 'rested on the belief that an outward-looking economy and trade would promote rapid economic growth which, in turn, would create social mobility and demands for political liberalization' (Rüland 2000, 440). Although an 'outlier' in terms of international human rights standards, it was not considered a pariah state in Asia (Boisseau du Rocher 2012, 174) and engaging with the country was not seen as negatively in ASEAN as in the West. Then-Prime Minister of Malaysia, Mahathir Mohamad, explained ASEAN's view: 'if it is outside, it is free to behave like a rogue or a pariah, while if it is inside, it would be subject to certain norms of behavior' (Agence France-Press 1997). One interviewee explained:

Of course ASEAN was criticized by Western countries at that time, especially when the junta military was in power ... But then we were convinced at that time that we need to engage constructively Myanmar within the family of ASEAN rather than outside ASEAN. ${ }^{18}$

This comprises the hope and intention to influence the country after admission (see Renshaw 2013, 37), also showing that ASEAN indeed had a concrete idea about appropriate behaviour. 'Constructive engagement surely does not mean total disengagement from principles. Instead, constructive engagement must allow Asean to use its influence on the Myanmar regime to check further departures from internationally-accepted codes of behavior' (Straits Times 1992).

The EU's approach rather reflected the idea of ASEAN membership for Myanmar as a reward after compliance with human rights standards. ASEAN, however, perceived that the pressure to do so did not consider that ASEAN membership is not a 'reward' for streamlining behaviour with regional standards, as is the case with EU accession.

\footnotetext{
${ }^{17}$ Interview with Surin Pitsuwan, Minister of Foreign Affairs Thailand 1997-2001 and ASEAN Secretary General 2008-2012, 1 May 2014.

${ }^{18}$ Interview with Ngurah Swajaya, Indonesian Ambassador to ASEAN 2010-2014, 12 March 2014.
} 


\section{Compliance}

ASEAN followed a strategy in which the acceptance of slow progress in Myanmar should lead to the final aim of aligning human rights and democracy practices with those at the regional level. 'So the approach is more "bring them in and we will make them become like us"'. ${ }^{19}$ Evaluating the different approaches towards human rights socialization, one interviewee explained:

I think that a gradual approach is the best, because we cannot treat them the same as what we see in Western countries. Because human rights are part of the culture, it's not that easy to develop that kind of culture, it takes time. ... But there is a progress of course; there is dynamism in itself, but of course not as fast as expected by the Western countries. ${ }^{20}$

The EU's strategy referred to its own compliance model, in which threat or pressure towards a country should lead to adherence to democratic norms. From the perspective of ASEAN, such an approach did not leave enough room for interactions possibly leading to good developments.

Yes, certainly it created the opposite outcome from what the Western countries would have liked to see. It only strengthened the resolve in ASEAN to bring Myanmar in. In the hope that we will be right in the longer run, that we can help change Myanmar, once we give Myanmar an opportunity to be in ASEAN. And give Myanmar more international diplomatic space. ${ }^{21}$

ASEAN thus rather perceived the EU's approach to be counterproductive.

\section{Measures in case of non-compliance}

At the time of Myanmar's accession process, there were no concrete institutionalized human rights standards in ASEAN against which to judge the violations happening in Myanmar. Although an 'outlier' label was attached to the country somehow, applying instruments of punishment such as sanctions was incompatible with ASEAN's membership concept. Among ASEAN elites, the EU's recourse to sanctions, especially connected with the 'quasi-sanctions' on ASEAN, was perceived to be inappropriate. One interviewee, from a Track II diplomacy network - where mostly nongovernmental members of Southeast Asian political elite try to bring together official and unofficial channels of diplomacy - remarked:

I think that the sanctions were a mistake, because sanctions punish the people. I know that there is an ethical component there. Sanctions are tools of the state to advance its foreign policy. I have no problem with that ... but it worked counterproductively. This is why I think ASEAN probably did a good thing somewhat in trying to keep the lines of communication open with Myanmar. ${ }^{22}$

\footnotetext{
${ }^{19}$ Interview with Ong Keng Yong, ASEAN Secretary General 2003-2007, 10 April 2014.

${ }^{20}$ Interview with Rahardjo Jantomo, former Director General for ASEAN, Ministry of Foreign Affairs Indonesia, 11 March 2014.

${ }^{21}$ Interview with Termsak Chalermpalanupap, ASEAN Secretariat 1993-2013, 5 March 2014.

${ }^{22}$ Interview with Carolina Hernandez, Chair of ISDS Philippines, 26 March 2014.
} 


\section{Obligations}

While becoming a member in the EU has clear relevance concerning human rights, defined in Chapter 23 of the Copenhagen criteria, there were no legal obligations in ASEAN with regards to human rights for an acceding country at the time of Myanmar's potential accession. The 1967 Bangkok Declaration (ASEAN 1967) as well as later $\mathrm{RO}$ documents makes no reference to human rights in this respect. Consequently, ASEAN membership in the case of Myanmar did not require human rights standards. From the ASEAN perspective, the EU's approach did not take into account Southeast Asian state heterogeneity. In fact, other ASEAN members or membership aspirants also displayed severe democracy or human rights deficiencies, rendering the $\mathrm{RO}$ thus inappropriate for conditioning membership in these aspects.

In sum, 'ASEAN's actions towards enlargement were consistent with its own perceived needs and normative preferences, which excluded human rights and liberal democratic standards from the normative foundation of ASEAN's regional culture of cooperation' (Manea 2009, 36). Related to these membership concept dimensions are also other ASEAN regional norms that are crucial for understanding its critical perception of the EU's agitation in the interregional interactions. ASEAN since its beginnings incorporated the desire for regional self-autonomy into its norm corpus, prompting the question of whether 'the memory of the colonial history constitute[s] a prism through which Southeast Asian stakeholders view the EU's attempts to promote democracy and human rights in this part of the world?' (Portela 2015, 41). Indeed, interviews and newspaper statements reveal that colonial legacy shaped ASEAN's perception of the EU's Myanmar strategy and its attempt to integrate ASEAN in its pressuring mechanism. The repudiative mindset is based on the fact that

ASEAN is averse to responding to external, especially western, pressure. To do so, is not simply politically difficult for an organization committed to non-intervention, but it comes very close to violating the founding raison d'etre of ASEAN itself. It should be remembered that western pressure which was applied to thwart Myanmar's original bid for membership was wholly counterproductive. (Davies 2014)

Similarly, Kavi Chongkittavorn, a journalist long involved in ASEAN regional affairs, explained:

The Western involvement was rejected, particularly by the Malaysian Prime Minister Mahathir. He said 'it is our own business'. Even today there is this talk about Mahathir who stood against this Western involvement. ... Western involvement also encouraged these countries, Indonesia and Malaysia, to say 'we are ASEAN'. This polarized and pushed the countries to see enlargement as an ASEAN issue. ${ }^{\prime 23}$

Further, ASEAN's critical perception was also moulded by the idea that the EU's Myanmar approach towards ASEAN did not sufficiently value the regional developments in democracy and human rights issues that just came into being. In fact, although '[i]n 1997, the nature of ASEAN suggested no concern with human rights' (Davies 2012, 14), the empirical analysis also revealed that ASEAN's membership debate about Myanmar was continuously accompanied by discussions about the role of human rights at the regional level, which arguably over time affected ASEAN's future vision of what membership means and how human rights relate to

\footnotetext{
${ }^{23}$ Interview with Kavi Chongkittavorn, journalist and former editor of The Nation, 29 April 2014.
} 
that (see Radtke 2014). Some member countries, journalists, NGOs and CSOs were working towards linking human rights to membership in order to make the issue a concern of the whole of ASEAN. Although official ASEAN circles intensively discussed Myanmar's domestic situation in the context of its accession, '[t]he intense heterogeneity of ASEAN member states necessarily limited that which was expressed regionally, and this created space for member state-driven discursive engagement to arise' (Davies 2014, 27). Some member states, especially the more democratic ones such as the Philippines, Thailand and post-Suharto Indonesia, together with Myanmar, led 'a series of discussions over the meaning of membership, and whether it should be significant for human rights standards' (Davies 2014, 27). In 1996, crackdowns on the National League of Democracy (NLD) in Myanmar prompted Philippine President Fidel Ramos to say that 'Asean's constructive engagement policy with Burma might be reviewed' (Sawatsawang 1996). Other elite representatives also demanded 'significant improvements in human rights in Burma as a prerequisite for that country joining the group' (Bangkok Post 1996b) or stating that 'Myanmar is not ready for membership because of domestic political behaviour' (Paribatra 1997). These ideas aimed at shaping the membership concept in ASEAN and linking it to political norms and stricter conditions such as democracy and human rights (see for example Jakarta Post 1995). An unnamed delegate after the 29th ASEAN ministerial meeting in 1996 said that 'Asean should review criteria for membership of the grouping, and decide whether these should include the enjoyment of compatible values in the matter of human rights' (Bangkok Post 1996a). However, the claimants did not have enough authority (yet) (see Checkel 2005; Davies 2014). Of course, at that phase there was no 'ASEAN language' of human rights that would have enabled the RO at an aggregated level to articulate such a position or elevate such norms towards membership conditions. Instead, '[i]ll-defined understandings of democracy and good governance were only just emerging within ASEAN and were only just being woven into regional agreements' (Davies 2014, 5). Importantly, in ASEAN the meaning of the membership concept developed along the accession cases, especially the case of Myanmar. This also shows that ASEAN membership norms were not static, but developed over time, partly due to the very episode discussed here. So while ASEAN's membership criteria from the beginning only referred to geographical and technical obligations, there seems to be another background today, especially with postASEAN Charter developments since 2008 and the existence of the ASEAN Intergovernmental Human Rights Commission since 2009. In addition, Laos (1997) and Cambodia (1999), whose accession processes were running nearly parallel to Myanmar's accession, also showed severe deficiencies in human rights and democracy. This, however, did not find the EU's attention or at least not in the same prominent way as the case of Myanmar. In sum, the EU's rationality-based idea of 'socializing' countries into rules before membership was difficult to reconcile with ASEAN's socialization approach towards Myanmar via discursive engagement. This approach, linked to ASEAN's membership concept, emphasized taking into account historical and cultural circumstances of the region, and was applied in an 'open-ended process, where questions of future identity, and the roles and obligations that flow from it, are at stake' (Davies 2014, 4). ${ }^{24}$

\footnotetext{
${ }^{24}$ Some studies have analysed the application of this approach, estimating that the approach has been inconsistently applied by ASEAN, thus leading to socialization failure rather than success; see Jones (2012).
} 


\section{The interregional relationship in light of the Myanmar conflict}

At the interregional level the EU linked ASEAN-EU dialogues to the question of Myanmar's accession to ASEAN, taking the opportunity to reinforce its negotiation approaches about the situation in Myanmar at the regional agenda (see Marchi 2014). The 12th ASEAN-EU Ministerial Meeting (AEMM) of foreign ministers in February 1997 hosted an exchange of views about Myanmar. ${ }^{25}$ An EU Declaration on the ASEAN accessions of Cambodia, Laos and Myanmar from 2 June 1997 states:

The EU would like ... to re-affirm its commitment to the EU-ASEAN dialogue, and to the promotion of shared values, including respect for human rights and democratic principles. It trusts that membership of ASEAN will further these aims in the new member[s] states and in particular in Burma/Myanmar, where the situation in this regard continues to be of serious concern to the international community. ${ }^{26}$

On 26 June 1997,

[t] ] Council discussed the implications for the EU of the accession in particular of Burma/Myanmar to ASEAN. The Council underlined that the deteriorating human rights situation in Burma/Myanmar is a matter of serious concern to the EU. ... It agreed that the opportunity of the EU-ASEAN dialogue should be used to discuss the situation in Burma/Myanmar. ${ }^{27}$

The EU aimed at dissuading ASEAN from accepting Myanmar or at least demanding adherence to human rights first. Also, the EU refused the country's participation in meetings with the rationale of not granting political legitimacy to the junta. Singapore's former foreign minister, Shunmugam Jayakumar, criticized the EU's inconsistent handling of the issue, saying that it 'made a little magic show to get around it. They held the meeting in Brussels under the fiction that, well, it was in the EU headquarters. So the Myanmar foreign minister was allowed. ${ }^{28}$ For meetings in ASEAN countries, the EU accepted Myanmar's inclusion under conditions such as specific seating requirements or signs for Myanmar as 'new member' (Tin Maung Maung Than and Mya Than, 2001, 252-257). However, ASEAN refused these demands, leading to the postponement or cancellation of different ministerial and Joint Cooperation Committee meetings between 1998 and 2000. In consequence, 'ASEAN-EU relations ... deteriorated markedly after admission of Burma to ASEAN' (Rüland 2000, 440). In fact, these developments took place although ASEAN and the EU basically shared a common idea and goal of wanting Myanmar to move towards democracy. Yet, the strategies in dealing with the problem diverged. 'The main difference lies in their application of policy instruments ... to influence long-term changes' (Oo and Grieg 1999, 99). Also, especially the rigour of criticism differed, which is connected to the fact that an RO's tools depend on its state heterogeneity. As the democracy levels of ASEAN countries varied

${ }^{25}$ The 12th ASEAN-EU Ministerial Meeting (AEMM), Singapore, 14 February 1997, 6018/97 (Presse 45), C/97/45, <http://europa.eu/rapid/press-release_PRES-97-45_en.htm?locale=en, Singapore>, accessed 30 May 2015.

${ }^{26}$ Declaration by the European Union on the accession of Cambodia, Laos and Burma/Myanmar to ASEAN, Luxembourg, 2 June 1997, 8637/97, E/59/97, <http://europa.eu/rapid/press-release PESC-97-59_en.htm>, accessed 30 May 2015.

${ }^{27}$ 2019th Council Meeting, General Affairs, Luxembourg, 26 June 1997, 9308/97, C/97/216, 12.

${ }^{28}$ Interview with Shunmugam Jayakumar, Singapore Foreign Minister Singapore 1994-2004, 17 April 2014. 
greatly, the RO could also not proceed with consensus-bound statements or measures including sharp democracy rhetoric. Thus, the EU 'has even been accused of having implemented a rather counterproductive discourse, allowing the Burma issue to damage its partnership with ASEAN' (Boisseau du Rocher 2012, 167). The EU's strategy included not only threatening the country through the application of sanctions, but it was also stigmatizing the junta leaders and internationally isolating the country-also from its Southeast Asian neighbours. However, 'when ASEAN unity is threatened, the organization will close ranks' (Davies 2012, 12). Hence, this strategy rather resulted in a 'unifying factor' among ASEAN, rallying together around the norm of regional self-autonomy (see Acharya 2009) and rejecting the EU's comportment, as the following interview quote suggests.

So we tried our best to explain to the ... dialogue partners like the EU and America that while we agree with the position that the Myanmar government should be more open, should not be keeping Aung San Suu Kyi under house arrest, the fact is that you are taking action against one of our members. And we had to stick around our member on principle. ${ }^{29}$

Of course, one must also consider possible effects of this approach. In one way, the stigmatization might have contributed to force ASEAN into a position where it had to critically reflect its enlargement practices, which in the longer term contributed to refining its membership concept and how it relates to human rights (see Radtke 2014; Davies 2014). However, stigmatization did not fit ASEAN's strategy which thus led to the two ROs following diverging strategies and leading to interregional frictions or discord. The French then-foreign minister, Hubert Védrine, in December 2000 remarked that the EU 'is shooting [itself] in the foot by linking the ASEAN dialogue with the question of Myanmar' (Boisseau du Rocher 2012, 169). From ASEAN's point of view, it was not understandable that the EU was critical towards ASEAN's 'constructive engagement' policy while the EU was also practicing a policy of 'constructive engagement' towards other autocratic regimes, for example the South African apartheid regime or North Korea. Foreign minister of Singapore Shunmugam Jayakumar stated, in a conversation with then Swedish foreign minister Anna Lindh, in 1998:

Do you know, on the ASEAN side, including me, we see the EU practicing double standards and being hypocrites.... You know, North Korea will not get a prize in human rights, right? How is it you want to send a high level delegation to North Korea to engage them, but you don't even give a visa to a Myanmar foreign minister? $^{30}$

Another important factor determined the strategic implications of ASEAN's partnership with Myanmar, which, in the view of ASEAN, was insufficiently considered by the EU: ASEAN's intention to counterbalance China's weight in the region. Philippine Foreign Affairs Secretary Domingo Siazon explained that 'ASEAN's relationship with Burma "has strategic implications-not only in the single dimension of human rights"' (Agence France Press 1997). ASEAN considered it wiser to include Myanmar in Southeast Asian processes than exclude it, as the latter would allow China to drag the country into its influence sphere. The fact

\footnotetext{
${ }^{29}$ Interview with Ong Keng Yong, ASEAN Secretary General 2003-2007, 10 April 2014.

${ }^{30}$ Interview with Shunmugam Jayakumar, Singapore Foreign Minister Singapore 1994-2004, 17 April 2014.
} 
that the EU-at least in its encounters with ASEAN—rather ignored Myanmar's strategic importance for ASEAN was not comprehensible among Southeast Asian leaders. More so, '[s]ome aspects of the European diplomacy are not understood and still raise doubts in the region (such as strict conditionality and so forth)' (Boisseau du Rocher 2012, 166). This produced a 'deadlock situation' that might have precluded a concerted action or more fruitful dialogue between ASEAN and the EU on the issue. From an ASEAN perspective, a more careful consideration on the EU side of ASEAN's on-going human rights developments, the RO's idea of socializing Myanmar into democratic standards and ASEAN's strategic preferences might have been useful for the interregional relations. One interviewee, the former Indonesian Ambassador to ASEAN, recalls the EU's handling of the Myanmar issue:

I talked to so many people from Europe ... to remind them 'Look, you are not fair in punishing ASEAN because of one member who in your opinion does not fulfil the obligation on human rights as well as democracy. It is unfair to punish 80 per cent, even more than 80 per cent of the people, while only 20 per cent are still in the process towards developing their own democracy and their human rights'. Every time, whenever we were having meetings there were some instances so that they cancelled the meeting because of Myanmar. But you should support and encourage this majority in order to influence the minority rather than punishing the majority because you like to punish the minority. So in my perception it was really a process of a struggle, a sacrifice by all of the ASEAN member states in order to really enable us to promote democracy in Myanmar. ${ }^{31}$

In sum, both organizations were devoted towards democratic reform in Myanmar, albeit they differed in their approaches. The tension in the encounter of different membership concepts thus impaired the interregional relationship.

\section{Conclusion}

This paper examined ASEAN's perception of the EU's approach towards Myanmar and the related interregional relations, arguing that differing membership concepts implied differing ideas about the role of sanctions and human rights in the Myanmar case. The results comprise three major points. Firstly, membership in ROs is defined by a multi-dimensional concept, where dimensions are differently defined in ASEAN and the EU. Secondly, the concept of membership explained ASEAN's critical perception of the EU's sanctions approach, which I have shown along the six conceptual key dimensions. Thirdly, this perception of the EU's approach not only strongly shaped ASEAN's human rights and democracy discourse, but also impaired ASEAN-EU interregional relations. In sum, the EU's toolkit-emanating from a more static, performance-oriented and conditional basis-was perceived in ASEAN to be incompatible with its dynamic approach, which encourages incremental developments over time. Further, the perception of the EU's approach as a confrontational strategy might have led to the loss of important opportunities for dialogue or cooperation. In conclusion, the complex dynamics of ASEAN enlargement and regional identity-building from an ASEAN perspective were not mirrored in the EU's approach. Indeed, ASEAN

\footnotetext{
${ }^{31}$ Interview with Ngurah Swajaya, Indonesian Ambassador to ASEAN 2010-2014, 12 March 2014.
} 
has evolved from an organization without a clear definition of the meaning of being a member and an absence of human rights and other democratic norms at the regional level, towards an organization where ideas about membership are much clearer and where human rights and democracy matter. The results of this paper encourage us to further study in detail mutual perceptions between regions as well as the related issue of conflictual interregional relations. Especially on the Myanmar conflict in ASEAN-EU relations, detailed information about the EU's perception could be useful in shedding more light on conflict in interregional relations. One recent example for the importance of such analyses is the resumption of ASEAN-EU talks about free trade agreement negotiations, announced in April 2015. Negotiations had failed in 2009, due to EU difficulties with Myanmar over democracy and human rights principles. In order to better evaluate today's developments it is essential to fully understand the past dynamics and processes of interregional relations.

\section{Disclosure statement}

No potential conflict of interest was reported by the author.

\section{ORCID}

Kerstin Schembera (D) http:/ / orcid.org/0000-0003-2977-3974

\section{Notes on contributor}

Kerstin Schembera works as Research Fellow at the Department of Politics and Public Administration/Centre of Excellence at the University of Konstanz, Germany. Her research focuses on comparative regional integration, especially Southeast Asia and Europe. Kerstin's dissertation examines enlargement and regional norm dynamics in the Association of Southeast Asian Nations (ASEAN). Email: kerstin.schembera@uni-konstanz.de

\section{References}

Acharya, Amitav (2009) Constructing a security community in Southeast Asia. ASEAN and the problem of regional order (London: Routledge)

Agence France-Press (1997) 'ASEAN stands firm on Burma's entry despite Western pressure', 1 May

Allison, Laura (2015) The EU, ASEAN and interregionalism. Regionalism support and norm diffusion between the EU and ASEAN (Basingstoke: Palgrave Macmillan)

ALTSEAN-Burma (2003) Special report: ready, aim, sanction!, Bangkok, November 2003

ASEAN (1967) The ASEAN declaration (Bangkok Declaration), Bangkok, 8 August

ASEAN (1997a) Declaration on the admission of the Union of Myanmar into the association of Southeast Asian Nations, Subang Jaya, Malaysia, 23 July

ASEAN (1997b) Protocol for the accession of the union of Myanmar to ASEAN agreements, 23 July

ASEAN (1997c) Second protocol for the accession of the union of Myanmar to ASEAN agreements, Subang Jaya, Malaysia, 16 October

ASEAN (2003) Joint communiqué of the 36th ASEAN ministerial meeting Phnom Penh Phnom Penh, 16-17 June

Bangkok Post (1996a) 'ASEAN formally receives Burma', 21 July 
Bangkok Post (1996b) 'Groups press ASEAN for Burma talks', 10 July

Bersick, Sebastian (2015) 'European perceptions of Asian regionalism: The role of multilateralism in Europe's image of Asia' in Martin Holland and Natalia Chaban (eds) Europe and Asia: perceptions from afar (Baden-Baden: Nomos), 327-340

Boisseau du Rocher, Sophie (2012) 'The European Union, Burma/Myanmar and ASEAN: a challenge to European norms and values or a new opportunity?', Asia Europe Journal, $10,165-180$

Bünte, Marco (2007) "'Problemstaat" Myanmar: Stabiles Regime, soziale Krise und das Dilemma der internationalen Gemeinschaft' [Problem State Myanmar: Stable Regime, Social Crisis and the Dilemma of the International Community], Sïdostasien aktuell, 6:2007, 31-49

Checkel, Jeffrey T (1999) 'Norms, institutions, and national identity in contemporary Europe', International Studies Quarterly, 43:1, 83-114

Checkel, Jeffrey T (2005) 'International institutions and socialization in Europe: introduction and framework', International Organization, 59:4, 801-826

Chew, Lee Kim (1997) 'ASEAN-EU meeting sets 'right tone for partnership", Straits Times, 15 February

Davies, Mathew (2012) 'The perils of incoherence: ASEAN, Myanmar and the avoidable failures of human rights socialization?', Contemporary Southeast Asia: A Journal of International and Strategic Affairs, 34:1, 1-22

Davies, Mathew (2014) Realising rights. How regional organisations socialise human rights (Abingdon: Routledge)

Dosch, Jörn (2001) 'The ASEAN-EU Relations: an emerging pillar of the new international order?' in S Chirathivat, et al. (eds) Asia-Europe on the eve of the 21st century (Bangkok and Singapore: Centre for European Studies at Chulalongkorn University and Institute of Southeast Asian Studies), 43-56

Gaens, Bart (ed) (2008) Europe-Asia interregional relations A Decade of ASEM (Aldershot: Ashgate)

Gilson, Julie (2005) 'New interregionalism? The EU and East Asia', Journal of European Integration, 27:3, 307-326

Hänggi, Heiner, Ralf Roloff and Jürgen Rüland (eds) (2006) Interregionalism and international relations (Abingdon: Routledge)

Hellquist, Elin (2014) 'Regional organizations and sanctions against members. Explaining the different trajectories of the African Union, the league of Arab States, and the association of Southeast Asian Nations', KFG Working Paper Series, No. 59:January 2014

Holland, Martin and Natalia Chaban (eds) (2015) Europe and Asia: perceptions from afar (Baden-Baden: Nomos)

Jakarta Post (1995) 'Challenges for ASEAN', 14 December

Jones, Lee (2010) 'ASEAN's unchanged melody? The theory and practice of 'noninterference' in Southeast Asia', The Pacific Review, 23:4, 479-502

Jones, Lee (2012) ASEAN, sovereignty and intervention in Southeast Asia (Basingstoke: Palgrave Macmillan)

Katanyuu, Ruukun (2006) 'Beyond non-interference in ASEAN: the association's role in Myanmar's national reconciliation and democratization', Asian Survey, 46:6, 825-845

Kelley, Judith G. (2013) 'The potential for organizational membership rules to enhance regional cooperation' in Miles Kahler and Andrew MacIntyre (eds) Integrating regions: Asia in comparative context (Palo Alto: Stanford University Press), 78-102

Keva, Silja (2008) 'Human rights and Burma/Myanmar in the ASEM dialogue' in Bart Gaens (ed) Europe-Asia interregional relations: a decade of ASEM (Aldershot: Ashgate), 101-114

Manea, Maria-Gabriela (2008) 'Human rights and the interregional dialogue between Asia and Europe: ASEAN-EU relations and ASEM', The Pacific Review, 21:3, 369-396

Manea, Maria-Gabriela (2009) 'How and why interaction matters', ASEAN's regional identity and human rights', Cooperation and Conflict, 44:1, 27-49

Marchi, Ludovica (2014) "Obstinate and unmovable? The EU vis-à-vis Myanmar via EUASEAN', Australian and New Zealand Journal of European Studies, 6:1, 55-73

Novotny, Daniel and Clara Portela (eds) (2012) EU-ASEAN relations in the 21st century (Basingstoke: Palgrave Macmillan) 
Oo, Zaw and Kai Grieg (1999) 'Carrots and sticks for democratisation in Burma: policies of the EU and the ASEAN ' in H. Stokke and A. Tostensen (eds) Human rights in development: global perspectives and local issues (The Hague: Kluwer Law International), 91-136

Palmujoki, Eero (1997) 'EU-ASEAN relations: reconciling two different agendas', Contemporary Southeast Asia, 19:3, 269-285

Paribatra, Sukhumbhand (1997) 'Is Burma ready for membership?', Bangkok Post, 22 May

Pedersen, Morten B (2008) Promoting human rights in Burma: a critique of Western sanctions policy (Lanham: Rowman \& Littlefield)

Petersson, Magnus (2006) 'Myanmar in EU-ASEAN relations', Asia Europe Journal, 4:4, 563-581

Portela, Clara (2011) European Union sanctions and foreign policy: when and why do they work? (London: Routledge)

Portela, Clara (2015) 'The European Union, human rights and Burma/Myanmar: 'elite' perceptions in Southeast Asia' in N. Chaban and M. Holland (eds) Europe and Asia: perceptions from afar (Baden-Baden: Nomos), 25-45

Portela, Clara and Pascal Vennesson (2013) 'Sanctions and embargoes in EU-Asia relations' in Thomas Christiansen et al. (eds) The Palgrave handbook of EU-Asia relations (Basingstoke: Palgrave Macmillan), 198-2010

Radtke, Kerstin (2014) 'ASEAN enlargement and norm change - a window of opportunity for democracy and human rights entrepreneurs?', Journal Of Current Southeast Asian Affairs, 33:3, 79-105

Reiterer, Michael (2002) Asia-Europe: Do they meet? Reflections on the Asia-Europe meeting (ASEM) (Singapore: Asia-Europe Foundation)

Renshaw, Catherine Shanahan (2013) 'Democratic transformation and regional institutions: The case of Myanmar and ASEAN', Journal Of Current Southeast Asian Affairs, 32:1, 29-54

Roberts, Christopher B (2010) ASEAN's Myanmar crisis: challenges to the pursuit of a security community (Singapore: Institute of Southeast Asian Studies)

Robles Jr, Alfredo C (2004) The political economy of interregional relations: ASEAN and the EU (Aldershot: Ashgate)

Robles Jr, Alfredo C (2008) The Asia-Europe Meeting. The theory and practice of interregionalism (Abingdon and New York: Routledge)

Rüland, Jürgen (2000) 'ASEAN and the Asian crisis: theoretical implications and practical consequences for Southeast Asian regionalism', The Pacific Review, 13:3, 421-451

Rüland, Jürgen (2014) 'Interregionalism and International Relations: Reanimating an Obsolescent Research Agenda?' in Francis Baert et al. (eds) Intersecting interregionalism. Regions, Global Governance and the EU (Heidelberg: Springer), 15-35

Rüland, Jürgen (2015) 'The unintended consequences of interregional democracy promotion: normative and conceptual misunderstandings in EU-ASEAN relations' in Mario Teló et al (eds) Interregionalism and the European Union. A post-revisionist approach to Europe's place in a changing world (Farnham: Ashgate), 267-284

Rüland, Jürgen, Gunter Schubert, Günter Schucher and Cornelia Storz (eds) (2008) AsianEuropean relations. Building blocks for global governance? (Abingdon: Routledge)

Sawatsawang, Nussara (1996) 'Top officials to discuss Burma request', Bangkok Post, 14 October

Sawatsawang, Nussara and Anuraj Manibhandu (1996) 'Alatas says Burma not an issue at ASEAN Meeting', Bangkok Post, 19 July

Schembera, Stefan, Patrick Haack and Andreas G. Scherer (2015) 'Making sense of decoupling through narration: the case of fighting corruption in global business (June 15, 2015). University of Zurich, Institute of Business Administration, UZH Business Working Paper No. 356

Schimmelfennig, Frank (2003) The EU, NATO and the integration of Europe. Rules and rhetoric (Cambridge, UK: Cambridge University Press)

Schimmelfennig, Frank, Stefan Engert and Heiko Knobel (2003) 'Costs, commitment and compliance: the impact of EU democratic conditionality on Latvia, Slovakia and Turkey', JCMS: Journal of Common Market Studies, 41:3, 495-518

Straits Times (1992) 'Silence may not be golden', 28 March 
Than, Tin Maung Maung and Than, Mya (2001) 'ASEAN enlargement and Myanmar' in C.L. Gates and Mya Than (eds) ASEAN enlargement: impacts and implications (Singapore: Institute of Southeast Asian Studies), 249-261

Villacorta, Wilfrido V (2009) Inter-regional cooperation in democracy building: prospects for enhanced ASEAN-EU engagement (Stockholm: International Institute for Democracy and Electoral Assistance)

Yeo, Lay Hwee (2003) Asia and Europe: the development and different dimensions of ASEM (London: Routledge) 